\title{
Assessment of Actual Irrigation Management in Kalâat El Andalous District (Tunisia): Impact on Soil Salinity and Water Table Level
}

\author{
Noura Ferjani ${ }^{1}$, Hedi Daghari ${ }^{2} \&$ Moncef Hammami $^{3}$ \\ ${ }^{1}$ Faculty of Sciences of Bizerte, University of Carthage, Zarzouna Bizerte 7021, Tunisia \\ ${ }^{2}$ National Agronomic Institute of Tunisia (INAT), University of Carthage, 43 avenue Charles Nicolle, Cité \\ Mahragène-Tunis 1002-Tunisia, Tunisia \\ ${ }^{3}$ High School of Agriculture of Mateur, University of Carthage, Bizerte, Tunisia \\ Correspondence: Noura Ferjani, Faculty of Sciences of Bizerte, University of Carthage, Zarzouna Bizerte 7021, \\ Tunisia. E-mail: noura_ferjani@yahoo.fr
}

Received: July 18, 2012 Accepted: March 11, 2013 Online Published: April 15, 2013

doi:10.5539/jas.v5n5p46 URL: http://dx.doi.org/10.5539/jas.v5n5p46

\begin{abstract}
The objective of this work is to assess water and soil salinity evolution in the irrigated area of Kalâat El Andalous. Soil salinity, crops yield, water table level and drainage water flow were monitored during the period May 2008-June 2010. The results showed that during irrigation season (May-September 2008), the supplied water amounts for drip irrigated crops (tomato, melon and squash) were higher than crop water requirements. In fact, the soil water content was always equal or higher than the field capacity. Average root zone $(0-60 \mathrm{~cm})$ electrical conductivity of the saturated past extract (ECe) was $2.3 \mathrm{dS} \mathrm{m}^{-1}, 2.8 \mathrm{dS} \mathrm{m}^{-1}$ and $3.0 \mathrm{dS} \mathrm{m}^{-1}$ in May 2008, May 2009 and May 2010 respectively. But at the irrigation season end, higher electrical conductivity $\left(8.4 \mathrm{dS} \mathrm{m}^{-1}\right)$ was recorded in the upper layer $(0-30 \mathrm{~cm})$. Along rainfall season, a soil salinity decrease was recorded in fact the average electrical conductivity reached $2.0 \mathrm{dS} \mathrm{m}^{-1}$. In order to reduce soil salinization (due to accumulated salts during irrigation season), farmers use crop rotation including rain fed crops and bare soil. Allover irrigation season, the highest drainage discharge $(192 \mathrm{l} / \mathrm{h})$ was recorded on July 2008 when the maximum irrigation water amount was diverted. Water table level shows a sustained rise when irrigation is relatively frequent during summer.
\end{abstract}

Keywords: drip irrigation, soil salinity, soil water content, drainage, water table, crop yield

\section{Introduction}

In arid and semi-arid areas, irrigation is used to maximize crop yields by minimizing water stress in the root zone. However, this is often done an ad-hoc manner. Excess of water supplies may cause rising of ground water table which may carry salts from subsurface to surface layers through capillary rise and evaporation (Turhan \& Baser, 2001). Soil salinization induced by capillary rise of shallow groundwater into the rooting zone plays a major role, nullifying pre-season salt leaching efforts, entailing yield decrease and seriously threatening economic growth and development (Grieve et al., 1986; Smets et al., 1997; Singh, 2004; Murtaza, 2006). Such evapo-concentration phenomenon associated with saline irrigation water is the main cause of soil salinization in irrigated districts (Stuyt, 2000). The salt accumulation in the soil profile is a widespread problem that seriously affects crop productivity throughout the world. More than $50 \%$ of the salinized areas in the Mediterranean basin are located in Algeria, Morocco, Spain, Tunisia and Turkey (Aragüés et al., 2011).

The use of drip irrigation may bring about a potential threat of the secondary soil salinization because no salt can be discharged from soil profile and salt build-up on the soil surface may be on the rise after long-term application of drip irrigation (Zhou \& Ma, 2005). Hence, it is essential that farmers have a clear understanding about irrigation practices' impact on the soil moisture content, on soil salinity and on crop yields. In fact, optimal irrigation management is supposed to maintain favorable soil water content, prevent salinity stress, and save water resources as much as possible. In Tunisia, Kalâat El Andalous irrigated district is one of the most affected area by salinization due to shallow groundwater level. This study aims to assess water and soil salinity evolution under the main frequently irrigated crops (tomato, melon and squash), rain fed crop (wheat) and bare soil in Kalaât El Andalous district. 


\section{Materials and Methods}

\subsection{Experimental Site}

The irrigated area of Kalâat El Andalous (latitude: $37^{\circ} 2^{\prime}$ to $37^{\circ} 6^{\prime} \mathrm{N}$; longitude: $10^{\circ} 5^{\prime}$ to $10^{\circ} 10^{\prime} \mathrm{E}$ ) is located on the end part of the Medjerda watershed (Figure 1), with an average annual potential evapotranspiration (ETP) of $1400 \mathrm{~mm}$ and an average annual rainfall of $490 \mathrm{~mm}$. Irrigation in Kalâat El Andalous district was launched since 1992 on a flood area that covers 2905 ha but the effectively irrigated surface varied over time, the maximum (about $1000 \mathrm{ha}$ ) was observed in summer. The district was divided into plots of 5 ha supplied by a flow rate of 3 1/s. All the irrigated area was equipped by a pressurized irrigation network and a subsurface drainage system with a length of $180 \mathrm{~m}$ and a depth of $1.5 \mathrm{~m}$ and spaced at intervals of $40 \mathrm{~m}$. The drainage outlet is below sea level, and the drainage waters are rejected in the Mediterranean Sea through a pumping station (SP4).

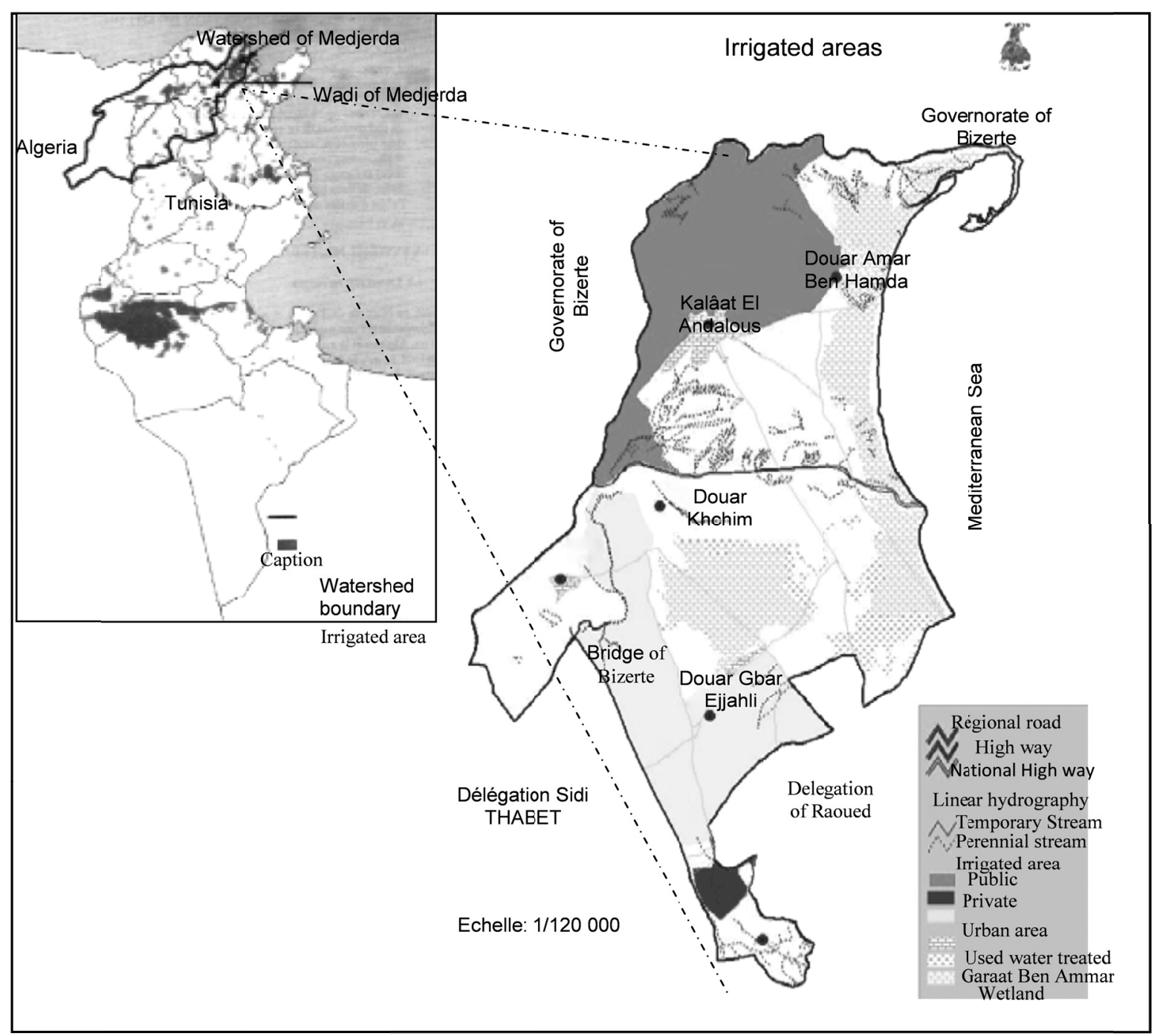

Figure 1. Irrigated area of Kalâat El Andalous

The soils have a fine texture, ranging from silty-clay to clayey-silt. The soil $\mathrm{pH}$ ranged from 7.3 to 8.9 , and the average bulk density is about $1.5 \mathrm{~g} / \mathrm{cm}^{3}$. The hydraulic conductivity varied between $0.2 \mathrm{~cm} / \mathrm{h}$ and $3.6 \mathrm{~cm} / \mathrm{h}$. Some physical and chemical characteristics of the soil in the experimental site were determined (Table 1). The irrigation water is pumped from Medjerda River which average Electrical conductivity reached $3.6 \mathrm{dS} \mathrm{m}^{-1}$. The general characteristics of the irrigation district (Aragüés et al., 2011) were presented in Table 2. 
Table1. Soils characteristics of Kalâat El Andalous area

\begin{tabular}{llccccc}
\hline \multirow{2}{*}{$\begin{array}{l}\text { Soil profile } \\
\text { depth }(\mathrm{cm})\end{array}$} & SP $(\%)$ & \multicolumn{2}{c}{ Volumetric water content $(\%)$} & \multirow{2}{*}{$\% \mathrm{OM}$} & \% $\mathrm{CaCO}_{3}$ & $\mathrm{pH}$ \\
\cline { 2 - 4 } & & $\mathrm{WP}$ & $\mathrm{FC}$ & & & \\
\hline $0-30$ & 50 & 20 & 35 & 4.6 & 42.2 & 8.9 \\
$30-60$ & 52 & 15 & 32 & 1.8 & 43.5 & 8.8 \\
$60-90$ & 57 & 26 & 42 & 1.3 & 44.0 & 8.6 \\
$90-120$ & 67 & 26 & 44 & 1.9 & 46.2 & 7.3 \\
$120-150$ & 55 & 27 & 44 & 1.3 & 36.8 & 8.5 \\
$150-180$ & 60 & 27 & 45 & 2.9 & 48.0 & 8.5 \\
\hline
\end{tabular}

SP: Saturation percentage, WP: Wilting Point, FC: Field Capacity, OM: Organic Matter.

Table 2. Water budget of Kalâat EL Andalous irrigation district during the hydrological year (2007/2008)

\begin{tabular}{ll}
\hline Parameter & Value \\
\hline Irrigation $(\mathrm{I}, \mathrm{mm})$ & 1187 \\
Precipitation $(\mathrm{P}, \mathrm{mm})$ & 676 \\
Reference $\mathrm{ET}_{\left(\mathrm{ET}_{0}, \mathrm{~mm}\right)}$ & 1412 \\
Crop ET $\left(\mathrm{ET}_{\mathrm{c}}, \mathrm{mm}\right)$ & 975 \\
Surface drainage $(\mathrm{Q}, \mathrm{mm})$ & 411 \\
\hline
\end{tabular}

A shallow (1.4 m deep) and salinized $\left(\mathrm{EC}=5.8 \mathrm{dS} \mathrm{m}^{-1}\right)$ water table covers all the nether part of the district. Such water resource is unsuitable for irrigation.

This study was carried out during May 2008-June 2010 in a farm plot of 2.38 ha (170 m x 140 m) equipped with drip irrigation system and drained by three subsurface pipes $D_{1}, D_{2}$ and $D_{3}$. Tables 3 and 4 showed the cropping pattern and the irrigation system characteristics respectively. Irrigations were practiced daily from $05 / 05$ to $07 / 08$ for tomato and from $15 / 05$ to $25 / 07$ for melon. Subsequently, irrigations were made once every two days. For squash, irrigation frequency was maintained on alternate days from 31/05 until 26/06, it was daily from 27/06 to $11 / 07$ then once every two days during the rest of the irrigation period. Irrigation duration ranges between 1.5 $\mathrm{h}$ /day and $4 \mathrm{~h}$ /day for tomato, between $3 \mathrm{~h}$ /day and $3.5 \mathrm{~h}$ /day for melon and squash.

Table 3. Cropping patterns during the period: May 2008-June 2010

\begin{tabular}{ll}
\hline Period & Soil occupation \\
\hline May 2008-September 2008 & Irrigated crops: tomato (1.0 ha), melon (1.0 ha) and squash (0.38 ha) \\
October 2008-November 2008 & Bare soil \\
December 2008-June 2009 & Rain fed wheat \\
July 2009-November 2009 & Bare soil \\
December 2009-June 2010 & Rain fed wheat \\
\hline
\end{tabular}

Table 4. Field cropping and irrigation system's characteristics during the period (May 2008-September 2008)

\begin{tabular}{ccccccc}
\hline Crops & Scientific Name & $\begin{array}{c}\text { Field } \\
\text { size }(\mathrm{ha})\end{array}$ & $\begin{array}{c}\text { Date of } \\
\text { plantation }\end{array}$ & $\begin{array}{c}\text { Row } \\
\text { spacing }(\mathrm{m})\end{array}$ & $\begin{array}{c}\text { Emitter } \\
\text { spacing }(\mathrm{m})\end{array}$ & $\begin{array}{c}\text { Average emitter } \\
\text { discharge }(1 / \mathrm{h})\end{array}$ \\
\hline Tomato & $\begin{array}{c}\text { Lycopersicum } \\
\text { esculentum } \\
\text { Cucumis mela L. }\end{array}$ & 1.0 & 3 May 08 & 1.5 & 0.4 & 2.1 \\
Melon & $\begin{array}{c}\text { CV. Sancha } \\
\text { Squash }\end{array}$ & 1.0 & 17 April 08 & 1.5 & 0.8 & 1.5 \\
\hline
\end{tabular}




\subsection{Measurements}

Field measurements included supplied water volume and salinity, drained water discharge and salinity, water table level and salinity, soil water content and salinity.

The supplied volumes $\mathrm{V}\left(\mathrm{m}^{3}\right)$ are determined as:

$$
V=N q T 10^{3}
$$

Where $\mathrm{N}$ is the number of emitters per hectare, $\mathrm{q}$ is the average emitter discharge $(1 / \mathrm{h})$, and $\mathrm{T}$ refers to the irrigation duration. The fixed emitters' discharges were measured weekly. The irrigation time was estimated according to farmer declaration and our survey. Daily climatic data were collected on a meteorological station located near the experimental plots. Reference evapotranspiration (ETo) was calculated using Penman-Monteith method (Allen, 1998). Crop evapotranspiration (ETc) was calculated as:

$$
E T_{c}=E T_{0} K_{c}
$$

where $\mathrm{K}_{\mathrm{c}}$ is crop's coefficient (Allen, 1998).

As given in Figure 2, rainfalls are negligible during the irrigation season (May-September).

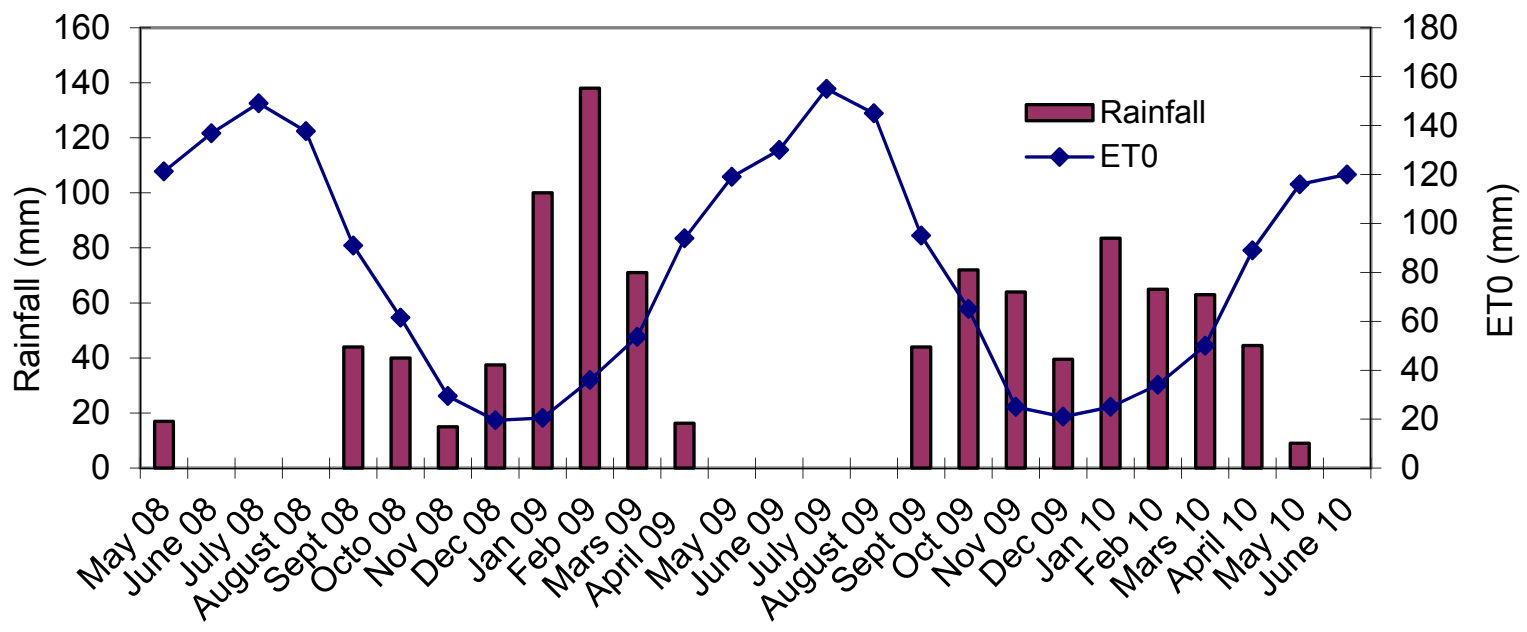

Figure 2. The repartition of precipitation and reference evapotranspiration $\left(\mathrm{ET}_{0}\right)$ during the study period

The water table levels were measured monthly using two piezometers. The first is localized in the plot, and the second is $50 \mathrm{~m}$ near the plot. Groundwater was sampled monthly for Electrical Conductivity (EC) measurements. In order to compute the removed (from the study area) salts amounts, monthly drained water discharge measurements were made on the subsurface pipes $\left(D_{1}, D_{2}\right.$ and $\left.D_{3}\right)$ ends. Furthermore, soil sampling was carried out in order to assess soil salinity (ECe) evolution in irrigated (tomato, melon and squash), rain fed (wheat) and in bare soil plots. Within each plot, three spots were randomly chosen where samples were done on the $0-30 \mathrm{~cm}$, $30-60 \mathrm{~cm}, 60-90 \mathrm{~cm}, 90-120 \mathrm{~cm}, 120-150 \mathrm{~cm}$ and $150-180 \mathrm{~cm}$ layers. These measurements were fortnightly during the irrigation period and monthly for the rest of the season.

For stored water computing, soil water contents (SWC), before (on 06/14) and after (on 07/12) irrigation, were determined gravimetrically in tomato and melon plots. Within each plot, three spots were randomly chosen where sampling was made on the $0-10 \mathrm{~cm}, 10-30 \mathrm{~cm}, 30-50 \mathrm{~cm}, 50-70 \mathrm{~cm}$ and $70-90 \mathrm{~cm}$. For roots distribution and crop yields' estimates, three representative plants from each plot (tomato, melon and squash) were randomly chosen where some agronomic parameters were determined namely: the root length, average fruit number per plant and average fruit weight. 
Soil, groundwater and drained water samples were analysed to determine electrical conductivity and $\mathrm{pH}$. The calcium $\left(\mathrm{C}_{\mathrm{ca}}\right)$, magnesium $\left(\mathrm{C}_{\mathrm{Mg}}\right)$ and sodium $\left(\mathrm{C}_{\mathrm{Na}}\right)$ concentrations were determined on saturated soil extracts (Black, 1965) and then sodium adsorption ratio (SAR) was calculated using the relationship:

$$
S A R=\frac{C_{N a}}{\left(C_{C a}+C_{M g}\right)^{0.5}}
$$

Gathered data were analysed using descriptive statistics (average value, minimum value, maximum value, coefficient of variation and standard deviation).

\section{Results and Discussion}

\subsection{Water Irrigation Volume, Salt Amount and Soil Water Content}

The daily supplied water volume varied during the irrigation season, from 4 to $16 \mathrm{~mm}$ for tomato, from 3 to 9 $\mathrm{mm}$ for melon and from 4.0 to $5.5 \mathrm{~mm}$ for squash crops. In tomato and squash plots, the maximum supplied water volumes were recorded in July: $4143 \mathrm{~m}^{3} /$ ha and $1130 \mathrm{~m}^{3} /$ ha respectively. The applied water amount decreased in August, mainly because the crop water requirement decreased. But these diverted amounts remained higher than the crop water requirements (Table 5).

Allover the irrigation season, the cumulated rainfalls were only $17 \mathrm{~mm}$. Thus, the applied salt amounts (by irrigation water) reached 24, 12 and 7 tons/ha in tomato, melon and squash plots respectively (Table 5). These results agree with those previously obtained in this region. In fact, Slama et al. (2004) recorded a total water amount equal to $10000 \mathrm{~m}^{3} /$ ha for drip irrigated tomato.

Table 5. Diverted water volumes and accumulated salt mass

\begin{tabular}{cccccc}
\hline Crops & $\begin{array}{c}\text { Beginning of } \\
\text { irrigation }\end{array}$ & End of irrigation & ET $_{\mathrm{c}}$ & $\begin{array}{c}\text { Diverted water } \\
\text { amounts } \\
(\mathrm{mm})\end{array}$ & $\begin{array}{c}\text { Accumulated salt } \\
\text { mass due to irrigation } \\
\text { (tons/ha) }\end{array}$ \\
\hline Tomato & 5 May 2008 & 15 September 2008 & 449 & 1030 & 24 \\
Melon & 15 May 2008 & 16 August 2008 & 332 & 503 & 12 \\
Squash & $1^{\text {st } \text { June 2008 }}$ & 15 September 2008 & 285 & 299 & 7 \\
\hline
\end{tabular}

Allover irrigation season, the water content was always higher or equal to field capacity (34\%) (Figure 3). In fact before irrigations, the average water content profile was higher than $30 \%$ and $33 \%$ in tomato and in melon plots respectively. The most important changes were observed on 12/07 within $0-10 \mathrm{~cm}$ where the soil water content increased from $34 \%$ to $39 \%$ underneath the emitter, from $32 \%$ to $36 \%$ at $10 \mathrm{~cm}$ and from $32 \%$ to $35 \%$ at $20 \mathrm{~cm}$ away of the emitter. In the deep layers $(60-90 \mathrm{~cm})$, water content distribution was approximately constant $(\approx 37 \%)$ throughout the soil profile. Rawlins and Rotas (1975) and Guohua et al. (2009) reported that compared with the border-irrigation, frequently drip and sprinkler-irrigated field help to maintain higher soil water content. 

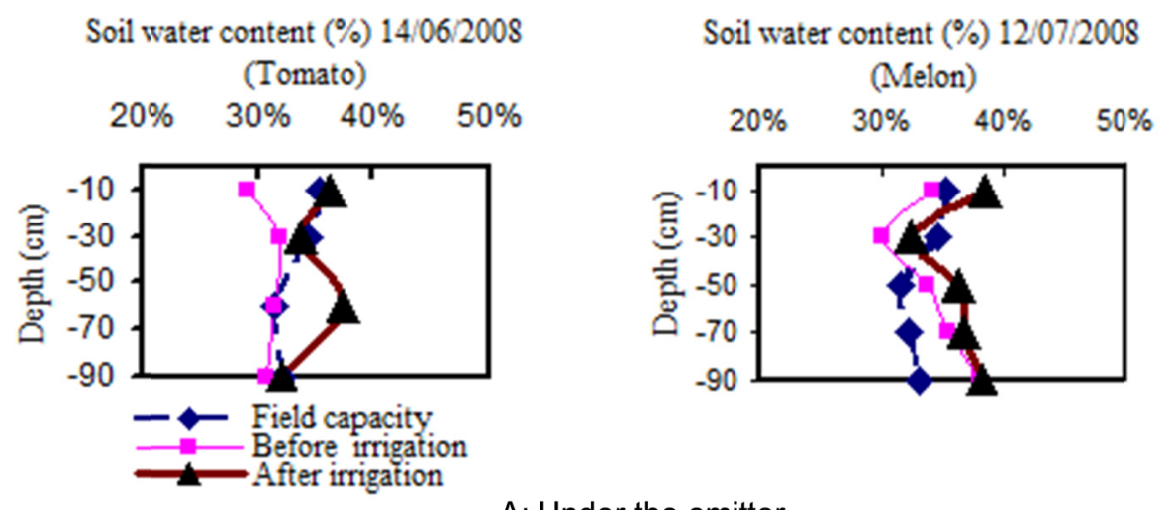

A: Under the emitter
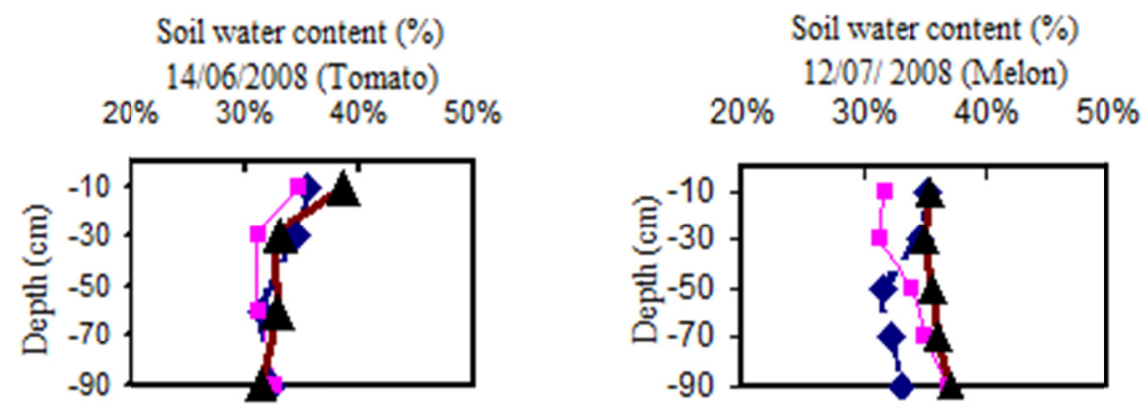

B: $10 \mathrm{~cm}$ away of the emitter

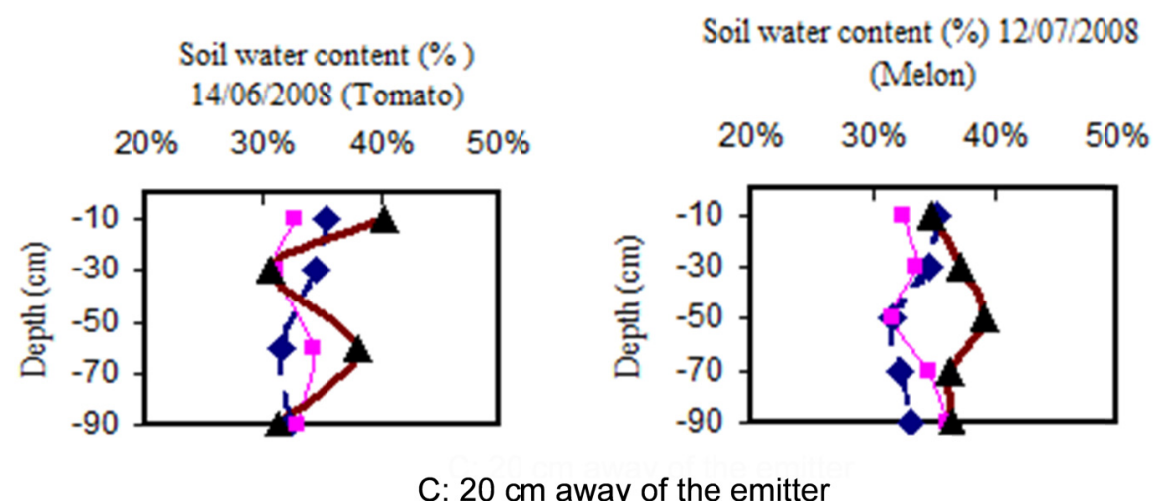

Figure 3. Volumetric water content profiles before and after irrigation: A: under the emitter; B and C: $10 \mathrm{~cm} 20$ $\mathrm{cm}$ away from the emitter respectively. All data are averaged values of three soil samples

\subsection{Soil Salinity Profiles}

Table 6 lists the descriptive statistics of the electrical conductivity (EC) at 31 measurement points, including minimum, maximum, mean, standard deviation and coefficient of variation (CV) during the period May 2008-June 2010. The EC variations are more pronounced in the upper layer $(0-30 \mathrm{~cm}, \mathrm{CV}=45 \%)$ than in the dipper layer $(150-180 \mathrm{~cm}, \mathrm{CV}=8 \%)$. Whereas, along two years, the soil profile salinity showed little variation.. In fact, within the root zone $(0-60 \mathrm{~cm}), \mathrm{EC}$ average values were 2.3, 2.8 and $3.0 \mathrm{dS} \mathrm{m}^{-1}$ in May 2008, May 2009 and May 2010 respectively (Figure 4). But these EC variations were more pronounced if only the irrigation season was considered. In fact, EC in the first layer $(0-30 \mathrm{~cm})$ increased from 1.9 up to $7.0 \mathrm{dS} \mathrm{m}^{-1}$, from 1.6 up to $8.4 \mathrm{dS} \mathrm{m}^{-1}$ and from 2.9 up to $7.7 \mathrm{dS} \mathrm{m}^{-1}$ (within tomato, melon and squash plots respectively (Table 7). 
Table 6. Some statistics of the soil electrical conductivity $\left(\mathrm{dS} \mathrm{m}^{-1}\right)$ during the period: May 2008-June 2010

\begin{tabular}{lllllll}
\hline & \multicolumn{7}{c}{ Depth $(\mathrm{cm})$} \\
\cline { 2 - 7 } & -30 & -60 & -90 & -120 & -150 & -180 \\
\hline Samples number & 31.0 & 31.0 & 31.0 & 31.0 & 31.0 & 31.0 \\
Average & 3.3 & 3.3 & 3.3 & 4.0 & 5.1 & 5.6 \\
Min. & 1.6 & 2.1 & 1.9 & 2.0 & 3.6 & 5.0 \\
Max. & 8.4 & 4.9 & 5.1 & 6.3 & 6.5 & 6.9 \\
Standard deviation & 1.5 & 0.8 & 0.7 & 0.8 & 0.7 & 0.4 \\
Coefficient of variation & $45 \%$ & $23 \%$ & $20 \%$ & $19 \%$ & $15 \%$ & $8 \%$ \\
\hline
\end{tabular}

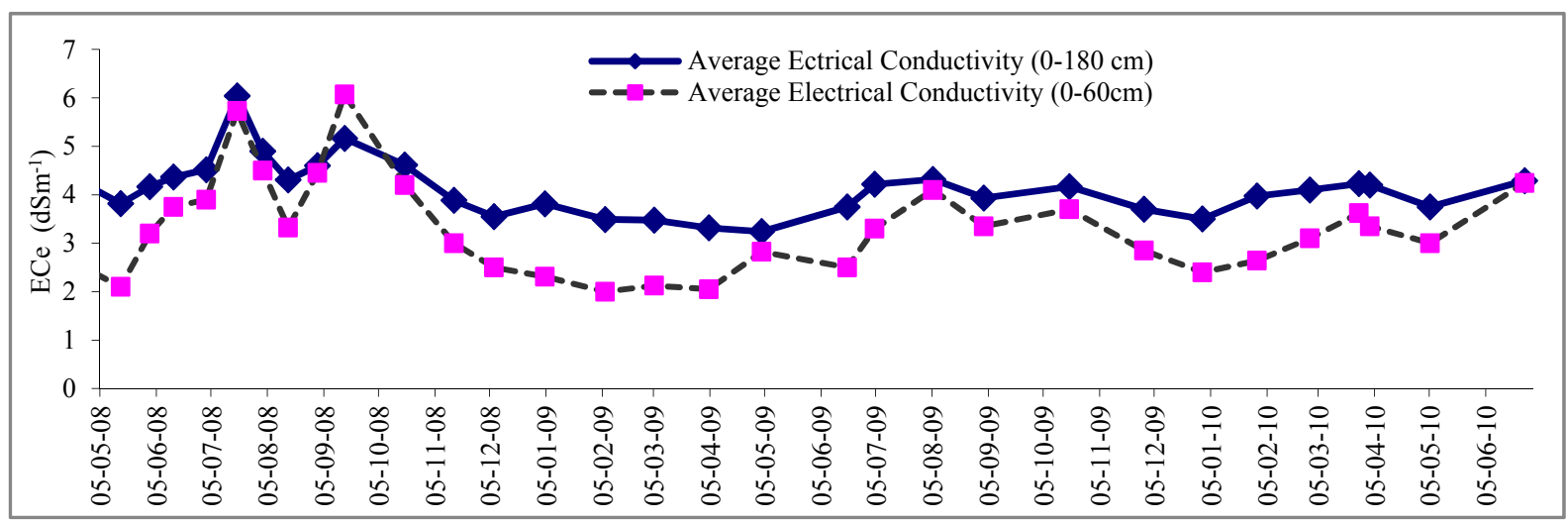

Figure 4. Average soil profile electrical conductivity during: May 2008-June 2010

In irrigated plots, the soil electrical conductivity (EC) changed allover crop growth stages. In fact, the root zone $(0-60 \mathrm{~cm})$ EC averaged value increased (between the beginning and the end of irrigation season) from $2.0 \mathrm{dS} \mathrm{m}^{-1}$ up to $5.3 \mathrm{dS} \mathrm{m}^{-1}$, to $3.3 \mathrm{dS} \mathrm{m}^{-1}$ and to $6.8 \mathrm{dS} \mathrm{m}^{-1}$ in tomato, melon and squash plots respectively. But, the highest EC values: $8.4 \mathrm{dS} \mathrm{m}^{-1}, 7.0 \mathrm{dS} \mathrm{m}^{-1}$ and $7.7 \mathrm{dS} \mathrm{m}^{-1}$ were recorded on 19/07 and on 16/09 in melon, tomato and squash plots respectively. So irrigation water supply caused a progressive salt accumulation over irrigation season. In the three (melon, tomato and squash) plots, such salinization was especially recorded in the top layer $(0-30 \mathrm{~cm})$.

The roots' distribution for tomato along soil depth was as fallow: $20 \%$ within the $(0-30 \mathrm{~cm}), 60 \%$ within the $(30-40 \mathrm{~cm})$ and $20 \%$ within the $(40-60 \mathrm{~cm})$ layers.

Along rainfall season, a decline in soil electrical conductivity was observed. In fact, EC values were: 3.8, 3.4, 3.5 and $3.9 \mathrm{dS} \mathrm{m}^{-1}$, measured on 4/01/2009, 6/02/2009, 29/11/2009 and on 30/01/2010 respectively. The lowest value $\left(1.6 \mathrm{dS} \mathrm{m}^{-1}\right)$ was recorded under rainfall conditions.

In the three irrigated plots, EC within the rooted layer $(0-60 \mathrm{~cm})$, ranged between 2.7 and $6.0 \mathrm{dS} \mathrm{m}^{-1}$. While in the rain fed wheat and bare soil plots, EC (within the $0-60 \mathrm{~cm}$ layer) ranged between 1.6 and $4.1 \mathrm{dS} \mathrm{m}^{-1}$ and between 2.9 and $4.0 \mathrm{dS} \mathrm{m}^{-1}$ respectively. Therefore, this salt accumulation was essentially due to an inadequate irrigation management. The inherent alkalinisation risks are obvious because the recorded maximum SAR values reached: $16.1,15.1$, and 10.7 in the irrigated squash, tomato, and melon plots respectively. Whereas in the rain fed wheat and in bare soil plots, SAR recorded values were: 4.5 and 6.2 respectively. 
Table 7. Soil electrical conductivity variations during irrigation season

\begin{tabular}{|c|c|c|c|c|c|c|c|}
\hline \multirow{3}{*}{ Crops } & \multirow{3}{*}{ Date } & \multicolumn{6}{|c|}{ Electrical conductivity $\left(\mathrm{dS} \mathrm{m}^{-1}\right)$} \\
\hline & & \multicolumn{6}{|c|}{ Depth $(\mathrm{cm})$} \\
\hline & & -30 & -60 & -90 & -120 & -150 & -180 \\
\hline \multirow{10}{*}{$\begin{array}{l}\text { Tomato } \\
\text { plot }\end{array}$} & $02 / 05 / 2008$ & 1.9 & 2.8 & 3.9 & 3.6 & 6.2 & 6.2 \\
\hline & $16 / 05 / 2008$ & 2.0 & 2.2 & 2.8 & 3.8 & 6.1 & 6.0 \\
\hline & $01 / 06 / 2008$ & 3.1 & 3.3 & 2.9 & 4.0 & 5.9 & 5.8 \\
\hline & $14 / 06 / 2008$ & 4.0 & 3.5 & 3.2 & 4.5 & 5.5 & 5.5 \\
\hline & 02/07/2008 & 4.1 & 3.7 & 4.0 & 4.2 & 5.2 & 5.9 \\
\hline & $19 / 07 / 2008$ & 6.5 & 4.9 & 5.1 & 6.3 & 6.5 & 6.9 \\
\hline & $02 / 08 / 2008$ & 5.1 & 3.9 & 4.1 & 4.2 & 6.1 & 6.0 \\
\hline & $16 / 08 / 2008$ & 4.1 & 2.6 & 2.6 & 5.6 & 6.0 & 5.0 \\
\hline & $01 / 09 / 2008$ & 5.0 & 3.9 & 3.0 & 4.0 & 5.9 & 5.8 \\
\hline & $16 / 09 / 2008$ & 7.0 & 3.7 & 4.3 & 3.4 & 5.5 & 5.7 \\
\hline \multirow{8}{*}{$\begin{array}{l}\text { Melon } \\
\text { plot }\end{array}$} & $02 / 05 / 2008$ & 1.6 & 2.3 & 2.0 & 3.8 & 5.2 & 5.9 \\
\hline & $16 / 05 / 2008$ & 1.8 & 2.5 & 2.3 & 3.9 & 5.7 & 6.0 \\
\hline & $01 / 06 / 2008$ & 1.9 & 2.1 & 2.3 & 3.9 & 5.6 & 5.7 \\
\hline & $14 / 06 / 2008$ & 3.0 & 2.1 & 2.4 & 4.0 & 5.9 & 6.2 \\
\hline & $02 / 07 / 2008$ & 5.1 & 3.3 & 3.9 & 3.9 & 5.9 & 6.1 \\
\hline & $19 / 07 / 2008$ & 8.4 & 3.8 & 3.5 & 4.9 & 6.5 & 6.8 \\
\hline & $02 / 08 / 2008$ & 5.3 & 3.8 & 3.2 & 4.5 & 6.1 & 6.3 \\
\hline & $16 / 08 / 2008$ & 4.1 & 2.6 & 2.6 & 5.6 & 7.7 & 6.9 \\
\hline \multirow{10}{*}{$\begin{array}{l}\text { Squash } \\
\text { plot }\end{array}$} & $02 / 05 / 2008$ & 2.9 & 2.7 & 4.1 & 4.5 & 5.1 & 5.2 \\
\hline & $16 / 05 / 2008$ & 2.7 & 2.6 & 4.1 & 4.9 & 5.4 & 5.3 \\
\hline & 01/06/2008 & 2.8 & 2.5 & 4.0 & 5.0 & 5.3 & 5.5 \\
\hline & $14 / 06 / 2008$ & 3.7 & 3.5 & 3.3 & 4.5 & 5.3 & 6.1 \\
\hline & 02/07/2008 & 3.8 & 3.6 & 3.4 & 5.2 & 5.4 & 6.0 \\
\hline & $19 / 07 / 2008$ & 3.9 & 3.7 & 3.5 & 5.9 & 6.3 & 6.5 \\
\hline & $02 / 08 / 2008$ & 3.7 & 3.8 & 3.5 & 5.1 & 6.1 & 6.2 \\
\hline & $16 / 08 / 2008$ & 3.8 & 4.1 & 3.9 & 5.5 & 5.4 & 5.7 \\
\hline & 01/09/2008 & 4.0 & 4.3 & 4.2 & 5.2 & 5.3 & 5.8 \\
\hline & $16 / 09 / 2008$ & 7.7 & 6.1 & 4.4 & 4.4 & 4.7 & 5.6 \\
\hline
\end{tabular}

\subsection{Crop Yield}

Measured crops' yields are shown in Table 8. In 2008, Harvests began on August the first and the $15^{\text {th }}$ for melon and tomato, and on September the first for squash. Tomato recorded yield was only 50 tons/ha: this result is significantly lower than Tunisian national average yield (80 tons/ha). According to Reina-Sanchez et al., (2005), tomato fruit is the most sensitive organ to the salinity, indeed significant yield reduction was recorded with irrigation water electrical conductivity higher than $2.5 \mathrm{dS} \mathrm{m}^{-1}$. Ayers (1977) reported that using irrigation water with EC equal to $2.3,3.4$ or $5.0 \mathrm{dS} \mathrm{m}^{-1}$ reduces tomato yield by 10,25 and $50 \%$ respectively. Cuartero and Fernandez-Munoz (1999) recorded a decrease of tomato fruit weight and number when irrigated with water which EC is equal to $2.5 \mathrm{dS} \mathrm{m}^{-1}$. Campos et al., (2006) compared the effects of five water salinity levels $(1,2,3$, 
4 , and $5 \mathrm{dS} \mathrm{m}^{-1}$ ) on industrial tomato yield. They concluded that total yield was reduced by $11 \%$ upon each unit increase of water salinity while fruit quality improved with increasing water salinity.

Table 8. Recorded and average national yields of some crops

\begin{tabular}{lll}
\hline Crops & Average recorded yield (tons/ha) & Average national yield (tons/ha) \\
\hline Tomato & 50 & 80 \\
Melon & 43 & 60 \\
Squash & 60 & 70 \\
Wheat & 1.6 & 2 \\
\hline
\end{tabular}

\subsection{Drainage Discharge}

The average flow rates were measured at the end of subsurface drainage pipes $\left(\mathrm{D}_{1}, \mathrm{D}_{2}\right.$ and $\left.\mathrm{D}_{3}\right)$ in tomato, melon and squash plots. Results obtained at several times (on 05/05, 31/05, 14/06, 12/07, 30/07, 16/08, 04/09 and on 16/09) during irrigation season (2008) are shown in Table 9. Measured drainage flow rate varied (between 1.5 and $3.2 \mathrm{l} / \mathrm{mn}$ ) according irrigations amounts and frequencies. Indeed, maximum drainage discharge was observed on July: when the maximum water volume was supplied. After the irrigation season, the drainage flow rate decreased sharply and annulled on the beginning of October. Drainage water electrical conductivity ranged between 4 and $8 \mathrm{dS} \mathrm{m}^{-1}$. Consequently, the salt masses leached by $\mathrm{D}_{1}, \mathrm{D}_{2}$ and $\mathrm{D}_{3}$ were $2.6,1.9$ and 1.7 tons/ha respectively. Tedeschi et al. (2001) found that average flow rate of the drainage water reached $26.71 \mathrm{~s} \mathrm{~s}^{-1}$ and 31.3 $1 \mathrm{~s}^{-1}$ respectively during non-irrigated and irrigation season. They concluded that exported salts mass was linearly correlated $(\mathrm{p}<0.001)$ with drained water volume that depended $(\mathrm{P}<0.001)$ on irrigation supplies.

During rainy season, the subsurface pipes outlets were flooded.

Table 9. Irrigation water amounts and average drainage flow rates during irrigation season

\begin{tabular}{|c|c|c|c|c|c|c|}
\hline \multirow{2}{*}{ Irrigation period } & \multicolumn{3}{|c|}{ Irrigation water amounts $\left(\mathrm{m}^{3} / \mathrm{ha}\right)$} & \multicolumn{3}{|c|}{ Average drainage flow rate $(1 / \mathrm{mn})$} \\
\hline & Tomato & Melon & Squash & Tomato (drain $\mathrm{D}_{1}$ ) & Melon (drain $\mathrm{D}_{2}$ ) & Squash (drain D3) \\
\hline May & 1567 & 400 & - & 0.6 & 0.2 & 0.3 \\
\hline June & 3030 & 2120 & 820 & 0.4 & 0.4 & 0.7 \\
\hline July & 4143 & 2170 & 1130 & 3.0 & 3.2 & 1.5 \\
\hline August & 1260 & 340 & 680 & 0.6 & 0.6 & 0.8 \\
\hline September & 300 & - & 360 & 0.1 & 0.0 & 0.2 \\
\hline
\end{tabular}

\subsection{Water Table Level and Salinity}

The water table levels were measured monthly using two piezometers localized in the irrigated plot (piezometer 1) and at $50 \mathrm{~m}$ away (piezometer 2). Water table levels measurements on piezometer 1 showed that groundwater was $1.3 \mathrm{~m}$ deep on 2 May 2008. But because of over irrigation supplies (between May and July 2008), the water table level rose up to $1.2 \mathrm{~m}$ on 12 July 2008. At the end of irrigation season (September 2008), the water table was $1.3 \mathrm{~m}$ deep. The maximum depths: $1.5,1.8$ and $1.7 \mathrm{~m}$ were recorded on 01/11/2008, on 05/07/2009 and on 26/06/2010 respectively. While during the winter season groundwater level increased up to $1.2 \mathrm{~m}$ and reached $1.3 \mathrm{~m}$ on May 2009 (Table 10), the same value observed on May 2008. Hence, groundwater shallow depths likely contributed to salt build-up in the soil through evapoconcentration process. Feng et al., (2005) reported that after irrigation season, the groundwater level remarkably rose from 2.9 to $1.3 \mathrm{~m}$ below soil surface. 
Table 10. Water table level and salinity variation

\begin{tabular}{|c|c|c|c|c|}
\hline \multirow{2}{*}{ Date } & \multicolumn{2}{|c|}{ Piezometer 1} & \multicolumn{2}{|c|}{ Piezometer 2} \\
\hline & Level (m) & Salinity $\left(\mathrm{dS} \mathrm{m}^{-1}\right)$ & Level (m) & Salinity $\left(\mathrm{dS} \mathrm{m}{ }^{-1}\right)$ \\
\hline $02 / 05 / 2008$ & 1.3 & 3.8 & 1.7 & 3.5 \\
\hline $14 / 06 / 2008$ & 1.3 & 3.5 & 1.8 & 3.4 \\
\hline $12 / 07 / 2008$ & 1.2 & 2.8 & 1.7 & 3.0 \\
\hline $16 / 08 / 2008$ & 1.3 & 3.1 & 1.8 & 3.4 \\
\hline $16 / 09 / 2008$ & 1.3 & 3.2 & 1.7 & 3.6 \\
\hline 01/11/2008 & 1.5 & 3.5 & 1.8 & 3.8 \\
\hline 06/12/2008 & 1.4 & 3.6 & 1.6 & 3.7 \\
\hline 06/02/2009 & 1.2 & 5.8 & 1.5 & 5.6 \\
\hline $02 / 05 / 2009$ & 1.3 & 4.8 & 1.6 & 4.6 \\
\hline 05/07/2009 & 1.8 & 5.5 & 1.9 & 5.4 \\
\hline $16 / 08 / 2009$ & 1.8 & 5.7 & 2.0 & 5.3 \\
\hline $01 / 11 / 2009$ & 1.6 & 5.3 & 1.8 & 5.2 \\
\hline $30 / 01 / 2010$ & 1.4 & 4.9 & 1.6 & 5.0 \\
\hline 27/03/2010 & 1.5 & 5.4 & 1.7 & 5.2 \\
\hline 07/05/2010 & 1.4 & 5.5 & 1.6 & 5.4 \\
\hline 26/06/2010 & 1.7 & 5.3 & 1.9 & 5.2 \\
\hline
\end{tabular}

On the beginning of irrigation season (05/05), the water table EC was equal to $5.5 \mathrm{dS} \mathrm{m}^{-1}$. On 12/07 (current irrigation season), measured water table EC was $2.8 \mathrm{dS} \mathrm{m}^{-1}$ (equal to irrigation water EC). Allover irrigation season, water table EC remained lower than $3.6 \mathrm{dS} \mathrm{m}^{-1}$. This decrease is due to the important irrigation water amounts that reached the groundwater. Since November the first, water table EC reached $5.8 \mathrm{dS} \mathrm{m}^{-1}$ on 06/02. It should be noted that the rainfall recorded along the year was $462 \mathrm{~mm}$ while the diverted water amount (was 1030 $\mathrm{mm}$ for tomato, $503 \mathrm{~mm}$ for melon and $299 \mathrm{~mm}$ for squash crops. As previously discussed, the broad irrigation water supplies were responsible for the significant water table rise which contributed to the soil salinity leaching. Therefore, Kalaat Landalous water table exhibits seasonal level and salinity variations, especially due to inadequate irrigation management.

\section{Conclusions}

This study was carried out during May 2008-June 2010 in a farm plot of 2.38 ha divided into: irrigated crops (tomato, melon and squash), rain fed crop (wheat) and bare soil. The supplied water amounts were higher than the total crop water requirements. Hence, during the irrigation season, the soil water content was always more than or near the field capacity. Therefore, water table level showed a sustained rise when irrigations were relatively frequent, and drainage flow rates increased accordingly. Whil along two years, the soil salinity varied slightly, but it was not the case over irrigation season. In fact, results showed an increase of the soil salinity essentially due to capillary rise of salt water from the water table. Soil salinity follow-up, on the three irrigated plots, showed that the most important concern was the top layer $(0-30 \mathrm{~cm})$ salinity increase. Fortunately, these accumulated salts (during irrigation season) were leached during the following rainfalls season.

In order to reduce an eventual soil salinization, farmers applied crops' rotation including rain fed crops and bare soil. Even though, using brackish water, wise irrigation management and regularly soil salinity monitoring are a sine qua non condition for soil and water resources sustainability.

\section{Acknowledgments}

This study was partially supported by the European Commission research project INCO-CT-2005-015031. The authors gratefully acknowledge the assistance of the technicians and students that actively participated in this work.

\section{References}

Allen, R. G., Pereira, L. S., Raes, D., \& Smith, M. (1998). Crop evapotranspiration-guidelines for computing crop water requirements. FAO Irrig. Drain. Paper 56. Rome, Italy. 
Aragüés, R., Urdanoz, V., Cetin, M., Kirda, C., Daghari, H., Ltifi, W., ... Douaik, A. (2011). Soil salinity related to physical soil characteristics and irrigation management in four Mediterranean irrigation districts. Agricultural Water Management, 98, 959-966.

Ayers, R. S. (1977). Quality of water for irrigation. J. Irrig Drain Div., 103, $135-154$. http://dx.doi.org/10.1016/j.agwat.2011.01.004

Black, C. A., Evans, D. D., White, J. L., Ensminger, L. E., \& Clark, F. E. (1965). Methods of Soil Analysis. Part 2. Chemical and Microbiological Properties (pp. 771-1572). Madison, Wisconsin: American Society of Agronomy Publisher.

Campos, C. A. B., Fernandes, P. D., Gheyi, H. R., Blanco, F. F., Goncalves, C. B., \& Campos, S. A. F. (2006). Yield and fruit quality of industrial tomato under saline irrigation. Sci. Agric., 63, $146-152$. http://dx.doi.org/10.1590/S0103-90162006000200006

Cuartero, J., \& Fernandez-Munz, R. (1999). Tomato and salinity. Sci. Hortic., 78, 83-125. http://dx.doi.org/10.1016/S0304-4238(98)00191-5

Feng, Z. Z., Wang, X. K., \& Feng, Z. W. (2005). Soil N and salinity leaching autumn irrigation and its impact on after the groundwater in Hetao Irrigation District, China. Agricultural Water Management, 71, 131-143. http://dx.doi.org/10.1016/j.agwat.2004.07.001

Grieve, A. M., Dunford, E., Marston, D., Martin, R. E., \& Slavich, P. (1986). Effects of waterlogging and soil salinity on irrigated agriculture in the Murray Valley: a review. Aust. J. Exp. Agric., 26, 761-777. http://dx.doi.org/10.1071/EA9860761

Guohua, L. V., Lan, Y. K., \& Li, S. W. (2009). Effect of irrigation methods on root development and profile soil water uptake in winter wheat. Irrig Sci. http://dx.doi.org/10.1007/s00271-009-0200-1

Murtaza, G., Ghafoor, A., \& Gadir, M. (2006). Irrigation and soil management strategies for using saline-sodic water in a cotton wheat rotation. Agricultural Water Management, 81, 98-114. http://dx.doi.org/10.1016/j.agwat.2005.03.003

Rawlins, S. L., \& Roats, P. A. C. (1975). Prospects for high-frequency irrigation. Science, 188, $604-610$. http://dx.doi.org/10.1126/science.188.4188.604

Reina-Sanchez, A., Romero-Aranda, R., \& Cuartero, J. (2005). Plant water uptake and water use efficiency of greenhouse tomato cultivar irrigated with saline water. Agricultural Water Management, 78, 54-66. http://dx.doi.org/10.1016/j.agwat.2005.04.021

Singh, R. (2004). Simulation on direct and cyclic use of saline water for sustaining cotton wheat in a semi-arid area of North-West India. Agricultural Water Management, 66, $153-162$. http://dx.doi.org/10.1016/j.agwat.2003.10.007

Slama, F., Bahri, A., Bouarfa, S., Chaumont, C., \& Bouhlila, R. (2004). Pratiques d'irrigation et rôle du drainage pour le contrôle de la salinité: Cas du périmètre irrigue de Kalaat Landelous en Tunisie. Projet INCO-WADEMED Actes du Séminaire Modernisation de l'Agriculture Irriguée Rabat, du 19 au 23 avril 2004.

Smets, S. M. P., Kuper, M., Van Dam, J. C., \& Feddes, R. A. (1997). Salinization and crop transpiration of irrigated fields in Pakistan' Punjab. Agricultural Water Management, 35, 43-60. http://dx.doi.org/10.1016/S0378-3774(97)00031-0

Stuyt, L. C. P. M., Dierickx, W., \& Martinez, B. J. (2000). Materials for Subsurface Land Drainage Systems (FAO Irrigation and Drainage Paper 60). Rome: Food and Agriculture Organization of the United Nations.

Tedeschi, A., Beltran, A., \& Aragüés, R. (2001). Irrigation management and hydrosalinity balance in a semi-arid area of the middle Ebro river basin-Spain). Agricultural Water Management, 49, 31-50. http://dx.doi.org/10.1016/S0378-3774(00)00117-7

Turhan, H., \& Baser, I. (2001). Salinity and plant growth (in Turkish with English abstract). Akd. U. Zir. Fak. Der., 14, 171-179.

Zhou, H. F., \& Ma, J. L. (2005). Studies on water-salt dynamics and balance of cotton-crop land in Tarim Irrigation Region. Journal of Irrigation and Drainage, 24, 10-14. 